\title{
Lobster in the Rain Forest: The Political Ecology of Miskito Wage Labor and Agricultural Deforestation
}

\author{
David J. Dodds
}

\section{Introduction}

The lobster on your plate may embody conflicting aspects of environmental conservation, international trade, and human rights for indigenous peoples. As small-scale societies are increasingly incorporated into the global market system, market participation can produce unexpected local effects by shifting the ecological impact of subsistence and market-related activities. The primary goal of this paper is to elucidate the links between a Miskito Indian community in Honduras and the international lobster trade. A secondary goal of this paper is to understand the conditions under which indigenous subsistence systems may or may not prove to be conservationist or sustainable and this necessarily includes the ecological impacts of markets and trade.

Links between wages, subsistence, and environment are here viewed from the perspective of political ecology, which seeks to relate macro-level political economic processes with micro-level dynamics of human ecology. The viewpoint of political ecology allows us to see how seemingly unrelated events like restaurant consumption of lobsters in the United States and deforestation in a Central American rain forest can be related in complex ways. A political ecological viewpoint also highlights many competing trade-offs that arise as small-scale indigenous economies become incorporated into the global market system. These trade-offs may involve conflicting aspects of environmental conservation, the forces of international trade, and human rights for indigenous peoples. Increased lobster harvesting may please the palates of North American restaurant diners, but may also create unforeseen negative consequences at the point of resource extraction: socially, by exposing Miskito lobster divers to bodily harm, and ecologically, by depleting Caribbean lobster populations. Yet from another point of view, Miskito lobster work has beneficial effects: socially, by providing cash income desired by the Miskito; and ecologically, by decreasing local pressure on primary forests, and by harvesting lobsters in a size-specific manner (in contrast to trap harvesting).

\section{Political Ecology, Deforestation, and Indigenous Peoples}

Political ecology is a research orientation that seeks to link macro-level political economic processes with micro-level aspects of human ecology (B.DeWalt and J.Pelto 1985; W.Durham 1995; M.Painter 1995; M.Schmink and C.Wood 1987; S.Stonich 1993). Political ecology is an emergent approach building upon previous research constructs 
(such as cultural ecology, human ecology, and political economy) to attempt the explicit identification of linkages between macro- and micro-level phenomena (see review by J.Greenberg and T.Park 1994). Political ecological research also involves "analytical level shifting" (E.Moran 1990). Susan Stonich, in her important work on the impact of export industries in western Honduras, defines political ecology in this way: "political ecology = political economy + human ecology" (1993:25). She further elaborates that it is:

\begin{abstract}
... a more inclusive framework that integrates political-economic and humanecological analysis. The political-economic analysis examines the interacting roles that social institutions (international, national, regional, and local) play in providing constraints and possibilities that affect human decisions that in turn affect those institutions as well as the natural environment. Human ecological analysis allows the consideration of crucial demographic factors, environmental concerns, and issues related to health and nutrition. It expands the perspective of political economy to include a systematic examination of the distribution and use of resources and the dynamic contradictions between society and natural resources (S.Stonich 1993:25).
\end{abstract}

Following Stonich's outline of the themes of political ecology, I first discuss the political economy of the Honduran lobster export industry and how the Miskito participate in it. Second, I discuss the human ecology of Miskito subsistence agriculture. Third, I present a quantitative analysis of the intersection between wage labor (lobster income) and the subsistence system (swidden agriculture), and how the interaction between wages and subsistence impacts local forest use. The topic of Miskito forest use is important because forest clearing for agriculture impacts the local landscape more than any other single activity of the Miskito economy.

During the last two decades, deforestation has become a central issue in Latin Americanist social and biological research. Efforts to understand causes of deforestation have also promoted the emergence of political ecology (M.Schmink and C.Wood 1987; W.Durham 1995). However, most studies of neotropical deforestation have focused on the role of wealthy business elites or migrant peasant farmers. These studies have identified a variety of macro-level causes of deforestation in the neotropics, including settlement schemes for opening frontier areas (E.Moran 1983; A.Stocks 1987), rural-to-rural migration (W.Loker 1995; N.Schwarz 1995), tax incentives for ranching (S.Hecht 1992; S.Hecht and A.Cockburn 1989), and the creation of pasture land for international and national markets in beef (M.Edelman 1995; J.Nations 1992). Only recently have field studies attempted to address links between monetary income, subsistence agriculture, and resultant local-level deforestation by indigenous peoples (E.Bedoya 1995; C.Behrens et al. 1994; R.Godoy et al. 1997; C.Simmons 1997). The point is that indigenous peoples, even when practicing traditional subsistence activities, have an impact on their local environments, though clearly they are not the major contributors to tropical deforestation.

The effects of markets on local subsistence systems are important: markets may influence the degree to which indigenous household economies remain sustainable (J.Nash 1994). Additionally, as global environmental changes have become more noticeable, many researchers have argued for the incorporation of indigenous subsistence techniques into sustainable management strategies for biodiverse neotropical areas (e.g., J.Alcorn 1991; J.Clad 1984; J.Clay 1988; D.Dufour 1990; J.Gradwohl and R.Greenberg 1988; and M.Oldfield). However, it is not clear that indigenous peoples always act in a conservationist manner toward the environment nor that indigenous subsistence systems are inherently sustainable (A.Alvard 1993; M.Colchester 1981; D.Dodds 1994; P.Henley 
1982; R.Hames 1987; P.Herlihy 1990; and A.Johnson 1989). The environmental sustainability of indigenous subsistence systems may depend largely on human population density, security of land tenure, indigenous ideological views about nature, and links to the market economy that may change the value and use of local resources (R.Hames 1991).

\title{
The Miskito
}

The Miskito are a Misumalpan-speaking people inhabiting the coasts and rivers of eastern Honduras and Nicaragua. The Miskito of Honduras number approximately 38,000 dispersed throughout 141 settlements in the Mosquitia region of eastern Honduras. ${ }^{1}$ Miskito culture has been created by the contact and mixture of indigenous Americans with African and European peoples. In contrast to many other indigenous peoples of the Americas, the Miskito have thrived since contact with Europeans, expanding in both population and territory since the mid-1600s (E.Conzemius 1932; M.Helms 1971; B.Nietschmann 1973). The contemporary Miskito continue to practice traditional subsistence activities such as swidden agriculture, fishing, and hunting in a manner technologically similar to many forest peoples of the neotropics.

During the last three centuries, the Miskito have worked at the periphery of the market economies of northern Europe, the United States, and more recently the nation-states of Honduras and Nicaragua; however, the Miskito have not become a peasantry dependent on the global capitalist structure for their daily survival (cf. C.Deere and A.de Janvry 1979). Instead, the Miskito have depended, first, upon a strong, indigenously derived subsistence core, augmented secondarily by participation in the monetary economy. Because the Miskito are neither a purely subsistence-based indigenous society, nor a rural peasantry, Mary Helms (1971:7) typologically defines the Miskito as a "purchase society":

\begin{abstract}
In order to emphasize the nonaboriginal, nonpeasant nature of Miskito society... I propose the delineation of a new sociocultural category, here termed the "purchase society," within which the nature of Miskito culture may be more profitably considered (cf. Helms 1969). The definitive characteristic of any purchase society is the articulation of local society with the wider complex world through economic channels of trade and wage labor, while political autonomy and a stable social organization are maintained. The term "purchase society" is suggested because it emphasizes both the economic referent in general, and the specific aspect of that referent which appears most important from the point of view of the local society, and towards which local adaptations will be directed, i.e., the need to obtain, to "purchase," through one means or another, foreign manufactured goods, which have acquired the status of cultural necessities. To be sure, something must be exchanged or sold in order to acquire these goods, but to the local population, that which is sold is merely a means to the all important end of purchasing.
\end{abstract}

The social relations of Miskito production for the monetized, capitalist economy have rarely resulted in the loss of Miskito economic autonomy. As Helms points out, the modes of surplus extraction that are key to the creation of peasantries have not been able to develop in the case of the Miskito. Since contact with Europeans, the extraction of natural resources on the Miskito Coast, especially in Honduras, has been temporary and periodic,

1. Estimate of Honduran population by author from national census data of Honduras (see D.Dodds 1994). Estimate of number of settlements from map by P.Herlihy and A.Leake (1993). 
thus preventing long term control by outsiders over Miskito labor and the natural resource base.

For the coastal Miskito of Honduras, the lobster export industry, in which Miskito males work for wages as divers or canoemen, is only the most recent incursion of the global market economy into eastern Honduras. Historically, the region has experienced a series of boom-and-bust industries, especially since the 19th century onward. These industries have been extractive in nature, focusing on rubber, gum, lumber, gold, coconuts, bananas, and other forest goods; and in most cases the Miskito were involved as wage laborers in these industries.

\section{Study Site and Methods}

The present analysis is based on fieldwork conducted for 13 months (1991-92) in Belen, a Miskito community located on a spit of land between the Caribbean Sea and a freshwater lagoon (Laguna de Ibans). Belen is also located within the Río Plátano Biosphere Reserve, created in 1980, and one of the largest reserves in Central America (P.Herlihy 1997). Ecologically, the northern portion of the reserve is characterized by pine savanna, broad leaf tropical rainforest, gallery forests along streams and rivers, and various lacustrine, riverine, and marine microenvironments. The population of Belen in 1992 was 431 persons, living within 49 households. Three of these households were ethnically ladino (of Hispanic descent and culture), but had long term roots in the region and the community. The three ladino households comprise the village's most successful merchants and shop owners. The majority of Miskito households cluster into 14 kin-based residence units or kiamps.

Local level data for this paper were collected primarily by interviews. To understand the lobster economy, a sample of male divers $(n=17)$ and canoemen $(n=7)$ was interviewed regarding amount of lobsters caught, lobster wages earned, and costs incurred during lobster work. Combined with census information and time allocation data (D.Dodds 1994), these interviews allow estimates of annual income from lobster work for each household. The total lobster earnings for the community of Belen in 1992 was at least $\$ 23,353$--and this is probably a conservative estimate (Table 1). During 1992, 34 males worked as divers, and 25 as canoemen. Among the 46 Miskito households of Belen, 87 percent received income from lobster work.

\section{Table 1. Estimated Income from the Lobster Export Industry to the Community of Belen, 1992 (in Honduran Lempiras) Mean Average Average Earnings Outings Worker

Note: Mean earnings per outing from Dodds (1994:187). Average outings per worker per year based on time allocation data which indicate that males aged 15 and over spend approximately one-quarter of their time at sea (Dodds 1994:195).

Exchange rate in 1992 was U.S. Dollars, \$ $1.00=$ Honduras Lempiras, L. 5.40. 
To understand Miskito agricultural patterns in Belen, interviews were conducted with male and female household heads in all Miskito households ( $n=46)$; of these 85 percent of households engaged in agricultural activities. Interview topics included crops planted, size of field plots, location and status of plots, and type of forest cleared for plots. To determine plot sizes, Miskito units of measurement were recorded as stated by interviewees. Because reported field sizes might be inaccurate, however, a sample of fields was physically measured and compared to reported size to establish a regression estimate of report bias. All agricultural areas reported in this paper (e.g., total area planted, primary forest lost to clearing) were corrected for report bias (see D.Dodds 1994: 248-252).

The residents of Belen are a good example of the purchase society and the way in which the Miskito obtain and use cash. For most adults, everyday life in Belen involves some contact with cash, whether in spending or acquiring it. The most common daily use of cash is for purchases of small food items (lard, salt, flour, sugar, coffee, rice, beans, garlic, onions, etc.) from stores (pulperías) located in a number of ladino and Miskito houses in Belen. These stores are stocked with a variety of useful commercial items (e.g., matches, cooking utensils, clothing, flashlights, radios) imported from La Ceiba or Trujillo. In addition to food and commercial goods, cash is important to Belen residents for health care (for traditional healing and western medicine), buying school supplies for children, buying tools for agriculture, and occasional travel. A survey of Miskito divers showed that they spent their lobster wages on food (95\%), clothes (89\%), liquor (66\%), their house $(63 \%)$, agriculture $(54 \%)$, medicine $(49 \%)$, school $(43 \%)$, cattle $(5 \%)$, and savings (3\%) (n=334 interviews, Proyecto Nautilo 1993: Cuadro No. 11).

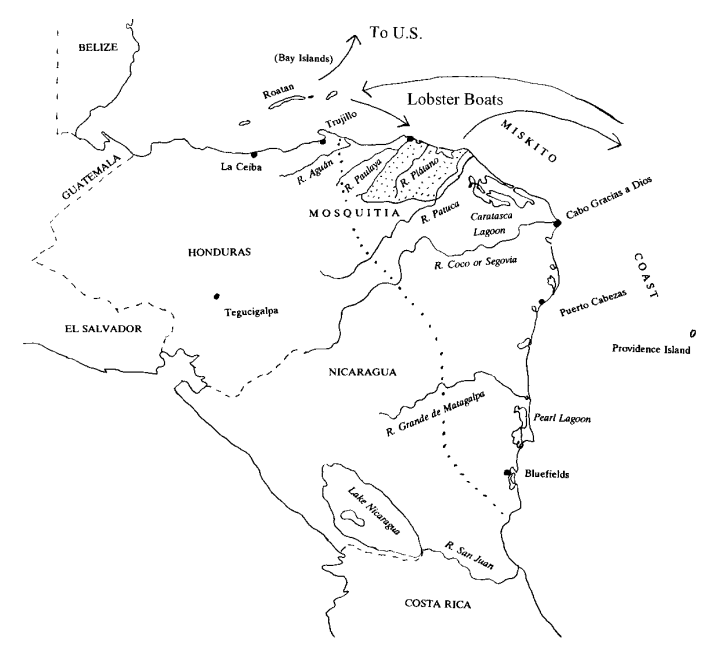

Figure 1. Flow of the Honduran lobster trade. Stippled area represents the Río Plátano Biosphere Reserve. 


\section{Political Economy: Miskito Lobster Work}

\section{The Honduran Lobster Export Industry}

Since the early 1970s, the lobster export industry has been the primary source of cash flow into the coastal Miskito communities of Honduras. Boats based in the Bay Islands come to the coastal communities of the Mosquitia to pick up Miskito men and boys as divers or canoemen. The boats then search for spiny lobster (Panulirus argus) in the continental shelf waters off Honduras and Nicaragua, and as far away as Colombia. After an excursion, the Miskito sea workers are then dropped off along the coast at their respective villages while the boats continue on to the Bay Islands; there, the catch of lobster tails is frozen and packed for shipping, mostly to the United States (see Figure 1). ${ }^{2}$

As of 1993, the size of the lobster and shrimp fleet based in the Bay Islands of Honduras was estimated at 275 to 300 boats and ships. This fleet sells its catch to eight major processing companies in the Bay Islands including Mariscos Agual Azul, Mariscos Hybur, Mariscos de Bahía, Exportadora de Mariscos (EXMARSA), Mariscos del Caribe (MARCASA), and Armadores Guanajeños (ITA 1993). Average fleet size for these companies is about twelve boats. A substantial number of independent lobster operators (using traps or divers) also supplies these sea food companies, owning between one and twenty-five boats (ITA 1993). One of the largest U.S. buyers of imported Honduran lobsters is the restaurant chain, Red Lobster USA (Economist 1997; T.Johnson 1993; D.Jukofsky 1994). The majority of the Honduran lobster catch is harvested by large boats using wire traps (e.g., see B.Nietschmann 1997:206). A lesser, though significant, portion of the total lobster catch in Honduras is provided by boats employing divers, most of whom are Miskito.

Reliable production data for the Honduran lobster fleet are difficult to obtain, and, for data collected in Honduras, are known by the government's fisheries directorate to be underreported: seafood companies may underreport production to avoid taxes (see DIGEPESCA 1992, 1994a, 1994b; see also M.Brunt 1981; ITA 1993). The most reliable data are estimates made by the Food and Agriculture Organization (FAO 1997) as depicted in Figure 2, illustrating trends in Honduran lobster production. Significant production began in the 1970s and peaked in 1986 at 5,320 metric tons; since then, annual harvest volumes have been less then one half the 1986 maximum. Overall, the FAO estimates that 823,813 metric tons of lobster have been harvested by the Honduran fleet from Caribbean waters during the period 1950-1995. The value of the lobster catch is also difficult to assess given poor data. Since the majority of the Honduran lobster catch is exported to the United States, the most reliable data seem to be kept by the U.S. Department of Commerce for the declared customs value of lobster imports from Honduras (USDOC 1989-1992). The maximum declared value for Honduran lobster imports to the U.S. in the 1990s was for 1991 at $\$ 38.7$ million. During 1996, the value of Honduran lobster imported to the United states was $\$ 25.8$ million (USDOC 1996). Thus, harvest of lobsters for export is a significant fisheries industry in Honduras.

Beginning in 1993, the Honduran government fisheries directorate (Dirección General de Pesca y Acuicultura, DIGEPESCA) began to enforce a lobster harvest moratorium in

2. B.Nietschmann $(1995 ; 1997)$ notes that the Caribbean lobster industry has also provided transport of cocaine from Colombia to the United States. 
an effort to protect the Honduran lobster banks from irreversible overexploitation. During the moratorium, or veda, lobster boats are restricted for several months a year to their ports in the Bay Islands, thus shortening the harvest season. Whether the moratorium will eventually increase yields is still unclear, though Miskito divers reported to me in 1997 that overall yields seem as low as before the moratorium was put into effect.

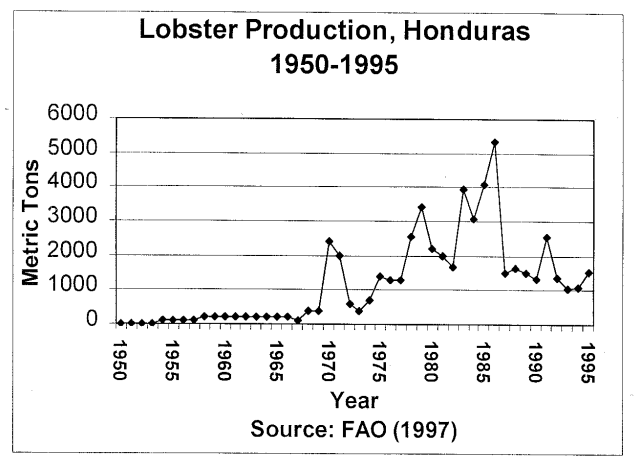

Figure 2. Lobster Production, Honduras, 1950-1995

\section{Miskito Lobster Work}

Most of the Miskito men and male youths of coastal communities in the Río Plátano Biosphere Reserve, either work, or have worked, in the lobster export industry within the Reserve as many as 700 males may be employed in lobster work (P.Herlihy and L.Hobson Herlihy 1992:10). In Honduras, at least 1,500-2,000 (W.Miller and M.Dagen 1990) and possibly as many as 4,000 (Proyecto Nautilo 1993:6) Miskito males work in the lobster industry. In Nicaragua, 2,000-2,500 Miskito males may work in the lobster industry (B.Nietschmann 1995:21).

Miskito males generally work at two kinds of lobster jobs: as divers (buzos) or canoemen (cayuceros). Divers and canoemen work in pairs, the canoeman accompanies the diver to the lobster bed, and maintains the position of the canoe (сауисо) above the diver; the lobsters and extra diving tanks are deposited in the canoe. Generally, it is the diver who is contracted and paid for the lobsters caught; in turn he shares his wages with the canoeman. Because of the physical demands and risks of diving, divers are generally older (Belen's mean age 29 years) whereas canoemen are generally younger (Belen's mean age 19 years). Divers make much more money at 10.00 Lempiras per pound of lobster caught, whereas canoemen are paid just 20 percent of the diver's catch at 2.00 Lempiras per pound of lobster (in 1992, United States equivalents, $\$ 1.85$ and $\$ 0.37$ per pound of lobster, respectively). Lobster work thus offers a high return to labor in wages. One successful 12-day outing can provide as much cash income to a diver as a year of working diligently in the fields to produce and market a cash crop (e.g., rice).

Lobster excursions or outings typically last for twelve to fourteen days, but may be shorter if the catch has been bountiful and the boat's cargo hold is full. (Divers report that in earlier years the lobsters were so plentiful that some outings lasted only five or six days until the boat hold was filled.) When a boat arrives offshore from Belen to start the excursion, the divers and canoemen pull their cayucos down from the beach into the waves and paddle out to meet the boat (Figure 3). The cayucos are then lifted by crane and 
stacked on deck for the trip out to sea. The boats, powered by diesel engines, usually take several days to arrive at the lobster banks. Once arrived at the banks, the boat drops off the diver-canoeman teams and circles among the canoes to replenish air tanks for the divers, and to unload the lobsters collected. During the day, divers make multiple descents to harvest lobsters by means of a hook and bag, and may also collect conch if encountered on the sea floor (Figures 4, 5). The boat passes the day making its rounds and finally picks up all the canoes for the night. The process begins again the next morning, and continues until the day that the hold is full of lobsters or supplies are low.

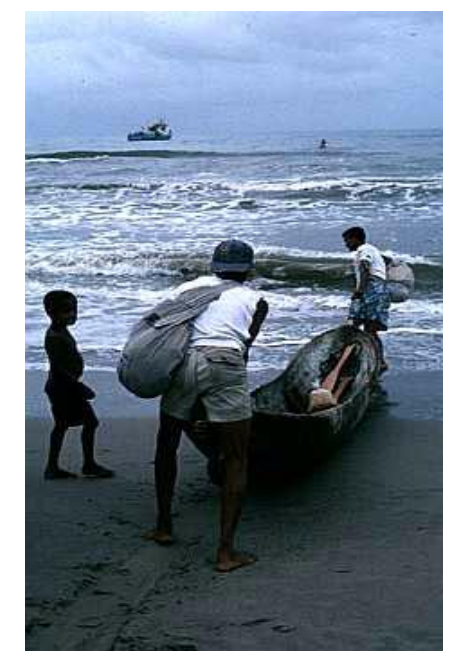

Figure 3. Young men of Belen leave for lobster boat on opening day of lobster season, August 1, 1997 (Photo by author).

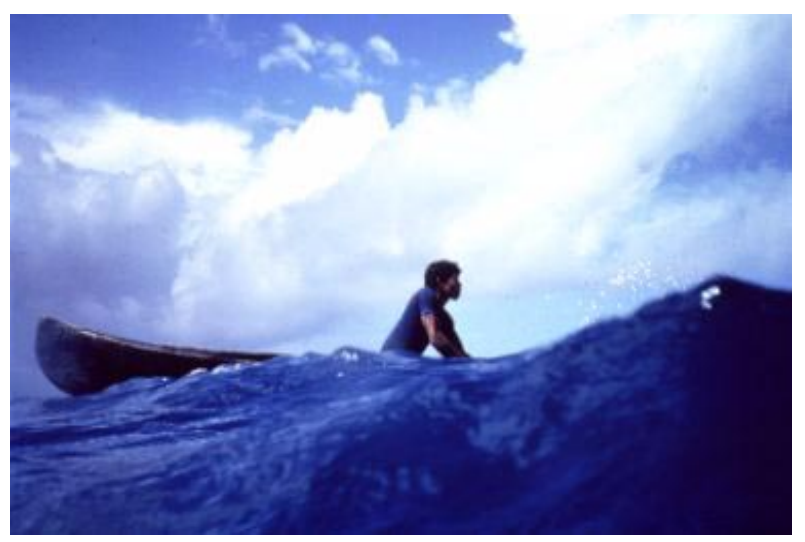

Figure 4. Canoeman waits for diver (Photo by Michael Bonfigli; used by permission). 


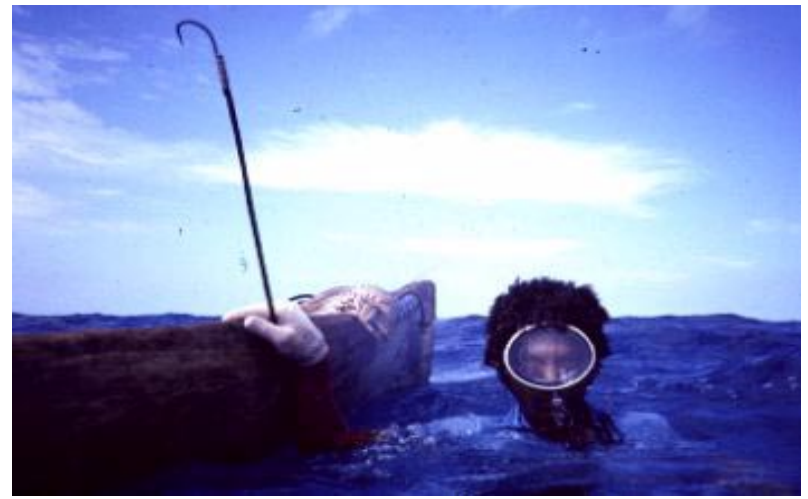

Figure 5. Diver with lobster hook (Photo by

Michael Bonfigli; used by permission.)

Though the Miskito work at the bottom rung of the lobster export industry, it is an organized and highly structured operation even at the local level. The boats are generally owned by Honduran businessmen of the Bay Islands. Boat captains, who work for the boat owners, are typically ladino, but a few are Miskito. Boat captains contract with diver foremen (sacabuzos) in the coastal communities to procure and pay the Miskito seaworkers. The most successful diver foremen (and sometimes forewomen) are usually ladino, though there are numerous Miskito diver foremen as well. It is the responsibility of the foreman to find enough men and boys to fill out the lobster boat's crew, to disburse advance pay to the workers, to make sure that the workers show up at the appointed time for work on the boat, and, when the workers return, to pay the workers based on the number of pounds caught by each diver. For his efforts, the foreman receives a flat fee (L.1,000 to L.3,000) negotiated with the captain, and dependent upon the foreman's reliability and experience.

Lobstering off the coast of Honduras was once common, yet the decreasing size of catches at increasing depths has caused the Honduran boats to search for distant lobster sources, many times illegally (i.e., without permits) in the waters of Nicaragua, Colombia, Jamaica and the Bahamas. Though lobster permits are possible to obtain for the waters of Nicaragua and Colombia, they are expensive and decrease potential profits. Many captains simply choose to enter stealthily into these waters hoping not to be caught and impounded by the authorities of the respective country (e.g, see B.Nietschmann 1995:20-24; 1997).

\section{Risk of Injury and Death}

During the first decade of the industry, lobsters were so plentiful along the "banks" (continental shelf) of Honduras and Nicaragua, that lobsters were found in relatively shallow waters and lung diving with no tanks was possible. By the early 1980s, lobster populations became depleted in the shallow waters and pressurized diving tanks were adopted by the divers to pursue the lobsters ever deeper. As depths have increased so have injuries and deaths to divers (W.Miller and M.Dagen 1990:5,12; Proyecto Nautilo 1993). Diving demands great physical stamina as divers may descend to depths of 90 feet or more, and can spend up to four or five hours a day underwater. The great depth and length of diving has led to the injury and death of many Miskito divers due to decompression 
sickness, or "the bends" (W.Miller and M.Dagen 1990). In addition to risk of decompression sickness, divers are exposed to sun, wind, heat, cold, strong underwater currents, and the risk of bites by sharks and barracudas. In Honduras, during 1976 to 1989, at least 56 Miskito divers died, and 157 were paralyzed or injured (W.Miller and M.Dagen 1990; T.Johnson 1993). In Honduras, a diving school was created at the impetus of the Moravian church in the coastal village of Cocobila. During 1994, the schools' graduates had experienced no diving deaths and a reduced rate of injury (Robert Armington, diving instructor for Escuela de Buceo, Cocobila, Gracias a Dios, Honduras, personal communication September, 1994.). During a field visit to the Río Plátano Biosphere Reserve in July of 1997, coastal residents told me of numerous cases of paralysis and death that had occured to divers in their villages since then. The plight of the Miskito lobster divers has received increasing press attention for both Honduras (Economist 1997; S.Stassel 1992; La Prensa 1997; W.Ring 1992; ) and Nicaragua (Ethnic Newswatch 1994; D.Jukofsky 1994), but continues to be a serious problem.

\section{Human Ecology: Miskito Swiddens}

\section{The Swidden System}

The historical core of Miskito subsistence has been swidden agroforestry distributed geographically in an infield-outfield system similar to swidden systems of Amazonia with regard to crops, tools, and biotope location (cf. W.Denevan 1984; D.Lathrap 1977). Immediately around houses within the village are planted small kitchen gardens; more substantive cultivars are typically planted at a distance from the village. The distribution of agricultural lands in various stages of cropping and fallows illustrates the extensive nature of Miskito agricultural land use. Altogether, Belen residents claim 166 total ha of land in various stages of activity: 27 ha as active crop land, 45 ha as active fallows, and 93 ha as abandoned fallows. The lands under active cultivation by the Belen Miskito in any one year comprise about 16 percent ( 27 of $166 \mathrm{ha}$ ) of the total lands claimed as agricultural holdings. In contrast to typical Amazonian swidden patterns, in which plots are cleared directly around periodically shifting settlements, the Miskito have planted their principal swiddens at some distance along naturally accessible waterways while maintaining permanent settlements on the Caribbean coast. Fields in various stages of use may be maintained in the village, on the coastal strip (near settlements), across the lagoon, and along banks and piedmonts of streams and large rivers such as the Río Tinto Negro or the Río Plátano up to $30 \mathrm{~km}$ away from place of settlement. Historically, this pattern of coastal settlement with riverine swidden farming has allowed the coastal Miskito increased access to opportunities for trade and wage labor while using the most fertile lands for agriculture.

Though local areas under agriculture have more than doubled in extent over the period 1960 to 1995 (D.Dodds 1998), much potential agricultural land is still available. Arable lands considered useful for traditional agriculture (i.e., levees and flatlands within $1 \mathrm{~km}$ of natural waterways) comprise about 19 percent of lands economically useful within the northern Reserve, approximately $141 \mathrm{~km}^{2}$ of $750 \mathrm{~km}^{2}$. And based on land use patterns in Belen, only 14 percent of the $141 \mathrm{~km}^{2}$ of arable lands within the northern Reserve were under active cultivation by the region's communities in $1992 .^{3}$

Miskito households in Belen typically maintain a total of 8 plots, of which 3 are under active crops during any given year, the other plots being in various stages of fallow. For 
1991-92, the average amount of land under active cultivation by Belen households was 0.70 ha per household complemented by a mean of 1.6 ha of active fallows and 2.9 ha of abandoned fallows. Households typically plant 3 plots during a year, with an average plot size of 0.23 ha (range $0.11-0.84 \mathrm{ha}$ ) and an average total area of land under active cultivation at 0.70 ha per household (range $0.13-2.48$ ha). When compared with nineteen Amazonian societies with similar swidden systems, mean plot size is slightly below the Amazonian tendency toward 0.4 and 0.6 ha, though total area under active cultivation per household falls well within the observed range of 0.01 to 4.6 ha (cf. S.Beckerman 1987:59).

At least 47 cultigens, all common to indigenous subsistence systems in the neotropics, are planted by the Belen Miskito (D.Dodds 1994, Appendix D). Of these cultigens, five major crops provide the bulk of carbohydrate dietary intake: manioc, bananas/plantains, rice, beans, and maize. Manioc and banana/plantain varieties are the most important of the five primary crops: at least 90 percent of planting households maintain active fields of these two crops. Manioc and bananas/plantains are clearly subsistence crops planted for direct household consumption. Rice, beans, and maize however, fulfill dual functions as subsistence and cash crops. Though households often cultivate rice, beans, and maize for direct consumption, these crops also retain monetary value as they can be dried, stored, and sold long after harvest. ${ }^{4}$

\section{Swidden Deforestation and Fallows}

In a swidden system, land is cleared for planting each year (Figures 6, 7.) In the case of the Miskito, farmers may choose to clear in primary forest (unta disang=virgin forest) or secondary forest grown up in fallowed fields (unta swapni=soft forest, or insla

3. The estimate for total lands presently under cultivation within the northern Río Plátano Biosphere Reserve was calculated as follows. Since Belen residents claim a total of 165.9 ha (in all stages of activity whether as active crops, inactive crops, or abandoned fallows), the amount of agricultural lands per person in Belen is 0.38 ha (= 165.9 ha / 431 persons). Based on the 1990 Cocobila clinic census, there are 5,046 persons in the northern Reserve. Assuming that swidden planting patterns are relatively similar between communities within the northern Reserve, the total amount of lands under cultivation should be approximately 1942 ha (5,046 persons x 0.38 ha per person), or $19.42 \mathrm{~km}^{2}$. Area of arable lands $\left(141 \mathrm{~km}^{2}\right)$ is estimated from a series of 1:50,000 maps of the Instituto Geográfico Nacional of Honduras for levees and flatlands within $1 \mathrm{~km}$ of natural waterways. Area of economically useful lands $\left(750 \mathrm{~km}^{2}\right)$ is determined from a 1:250,000 scale map (IGN 1983, Brus Laguna, ND 16-4) with these approximate boundaries: from the coast near Barra Plátano southward along the east bank of the Río Plátano to Las Marías; thence across the Guapinyari watershed skirting Mount Baltimore to Los Encuentros at the confluence of the Río Sico and Rio Paulaya; thence northward to the coast following the west bank of the Río Tinto Negro.

4. In addition to the five major crops, other crops, planted in lesser quantities, remain important to the Miskito: these include malanga, sweet potato, squash, and ñame. A large variety of fruit trees are planted both in villages and in distant agricultural plots, among them: oranges, lemon, lime, avocado, breadfruit, nance, papaya, coconut, mango, peach palm, and cashew. 
prata=old field). Thus, two variables are important to the overall extensification of swidden systems: (1) the proportion of area cleared from new versus previously used and fallowed lands; and (2) the length of fallow time.

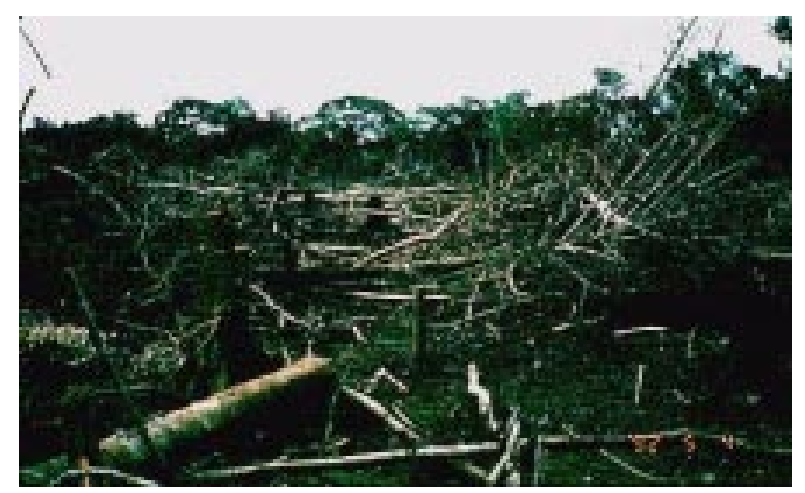

Figure 6. Swidden field after clearing and partial burn (Photo by author).

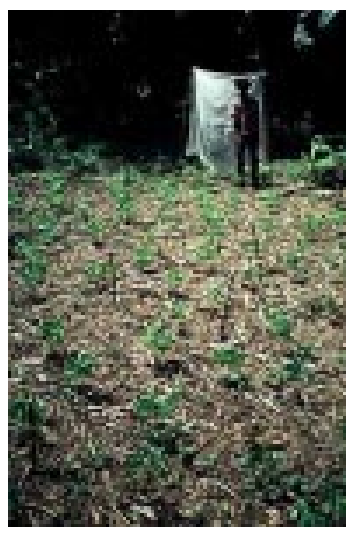

Figure 7. Miskito man in intercropped swidden of newly planted manioc cuttings and bean plants. Hanging sheet is a scarecrow (Photo by author).

With regard to the proportion of clearing from new versus fallowed lands, approximately 37 percent of the planting area in 1991-92 was cleared from primary forest; 63 percent was cleared from secondary forest in agricultural fallows. Table 2 summarizes the aggregate planting pattern for Belen by crop planted and ha cleared from primary and secondary forest. Though manioc and rice account for the largest areas planted, rice contributes most to primary forest loss (45 percent of primary forest cleared, or 4.355 of 9.724 ha). Miskito farmers describe rice as needing "strong" soil-so it is best to plant rice in "new" land cleared from primary forest. Additionally, planting rice in a plot cut from primary forest reduces later weeding labor since weeds have not previously become established in the plot. Taken together, the three cash crops (rice, beans, maize), account for 48 percent of primary forest loss by Miskito swiddens. Among the 46 Miskito 
households of Belen, 39 planted crops during 1991-92, and 19 planted their crops in areas cleared from primary forest.

The other key variable in swidden extensification is fallow length: the longer the fallow, the more extensive the agricultural system. When the Belen Miskito clear new fields from fallows, they report fallow times ranging from 1 to 40 years, with median and modal lengths of 5 years (mean 6.89 years, $n=99$ plots). A fallow time of five years is short for a "forest fallow" system as defined by Boserup (1981:29), who postulates fallow times between 15 and 25 years for forest-fallow systems. In the case of the Miskito, the short fallow time seems not to be an indicator of land scarcity and agricultural intensification (as per Boserup). The emic reason given by Miskito farmers for the fiveyear fallow is that it is easier to clear secondary forest than primary forest; therefore, planting in secondary forest is desirable because it saves labor. If a farmer cuts secondary forest before five years of fallow have passed, the plot is usually full of dense weeds and underbrush which are difficult to cut; and waiting longer than five years also means more labor to clear more established woody vegetation. The Miskito explanation is supported by ecological research: Uhl and Jordan (1984:1479) document that the understory of a naturally regrown swidden plot, cleared from a rain forest in Venezuela, begins to thin at approximately 5 years.

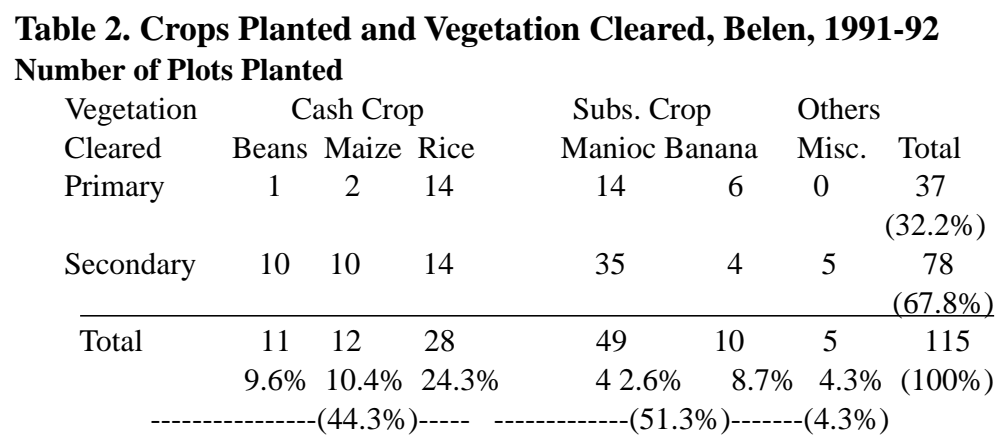

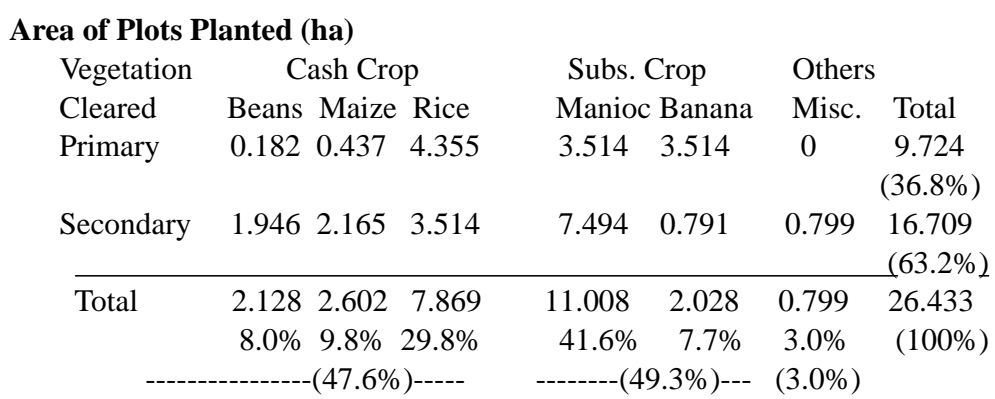

Note: Data are for households planting crops $(\mathrm{n}=39)$ in 1991 and 1992, and for which interviewed heads of household identified the type of vegetation cleared to make swidden fields. "Other" crops are cases of miscellaneous minor crops such as malanga, pineapple, watermelon, and yam.

Though lobster work is exclusively a male activity, both males and females participate in agricultural activities. Time allocation observations in Belen, following the method of random spot observation (A.Johnson 1975), showed that Miskito males 16 years and older engaged in 1.3 hours per day in agriculture versus 0.9 hours for females aged 16 and older 
(D.Dodds 1994:195). Of all agricultural tasks, clearing work, whether for primary or secondary forest, is the most gender-divided and is primarily a male activity since it involves understory clearing with a machete and heavy cutting of tree trunks with a steel axe. Planting is often done as a mixed-sex family group activity, as is harvesting of more labor intensive crops like rice. Root crops like manioc are often harvested by women who must replenish household food stocks every few days, even when men are away at sea. Weeding with machetes or hoes is more often done by men (especially for cash crops like rice, beans, and maize), but women also weed. Within the gender division of agricultural labor, clearing of land is constrained most by male labor. Women who are single or whose spouses are away typically prevail upon male relatives or hire male day-laborers to clear their land.

To summarize, the Miskito place pressure on their local ecosystem through swidden agriculture by clearing primary forest in areas not previously incorporated into the swidden system. The Belen Miskito practice a five year fallow to reduce clearing labor inputs as the successional understory thins. The key variable promoting deforestation is the proportion of agricultural lands cleared each year from primary forest versus secondary forest, and this is influenced by crop choice, especially the cultivation of rice, which can be stored and sold as a cash crop. The most important labor constraint to land clearing is availability of male labor.

\section{Analysis}

From the preceding narrative, it is clear that lobster income and subsistence agriculture are important to the Miskito household economy. But how do wage labor and subsistence activities intersect to affect local resource use? Does lobster income affect planting patterns and forest clearing?

Since data on lobster work and agriculture were collected on households throughout Belen, it is possible to understand how lobster income and planting patterns interact, at least for the research village. Table 3 summarizes the co-occurrence of planting pattern and lobster income for the 46 Miskito households of Belen. (The three ladino households are removed from the following analyses because they are unrepresentative of the Miskito subsistence economy). During 1991 and 1992, 87\% of households had lobster income, $85 \%$ of households planted crops, and $100 \%$ of households had either lobster income or planted crops.

Table 3. Co-Occurrence of Planting Patterns and Lobster Income for Miskito Households in Belen, 1992

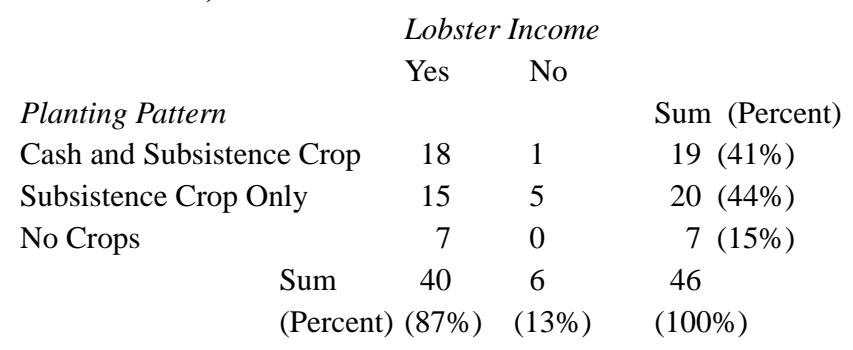

Note: Cash crops are rice, beans, maize. Subsistence crops are manioc and bananas/ plantains (Musa spp.). 


\section{Differences Between Non-Deforesting and Deforesting Households}

Because we wish to know about the impact of households on the forest, it is first useful to compare characteristics of households by type of forest cleared (Table 4). Households that cleared any of their fields from primary forest ("deforesters") are compared to households which planted fields only in areas cleared from secondary successional plots ("non-deforesters"). A Kruskal-Wallis test comparing means of ranked values for nondeforesting and deforesting households reveals that deforesting households plant significantly larger areas of total land (HHPLANT, $\mathrm{p}<.01$ ) as well as significantly larger areas in cash (HHCASH, p<.05) and subsistence crops (HHSUBS, p<.05). However, there is no significant difference in estimated amount of lobster income (HHLOBST), household size (HHSIZE), or household dependancy ratio (HHDEP). Thus the comparison of non-deforesting and deforesting households may indicate a rather simple pattern: that larger planting areas for any crop are more likely to result in deforestation (clearing of primary forest).

\begin{tabular}{|c|c|c|c|c|c|c|}
\hline \multirow{3}{*}{$\begin{array}{l}\text { Variable } \\
\text { HHPLANT }\end{array}$} & \multicolumn{2}{|c|}{$\begin{array}{l}\text { Non-Deforesters } \\
(\mathrm{n}=27)\end{array}$} & \multicolumn{2}{|c|}{$\begin{array}{l}\text { Deforesters } \\
(\mathrm{n}=19)\end{array}$} & \multicolumn{2}{|c|}{$\begin{array}{l}\text { Kruskal-Wallis } \\
\text { Test }(\mathrm{df}=1)\end{array}$} \\
\hline & Median & Mean & Medic & Mean & $\mathrm{H}$ & $\mathrm{p}$-value \\
\hline & 2927 & 3917 & 7099 & 8767 & 8.709 & $0.0032 * * *$ \\
\hline HHCASH & 0 & 769 & 2549 & 2194 & 5.640 & $0.0176 * *$ \\
\hline HHSUBS & 1818 & 2872 & 5098 & 5872 & 5.860 & $0.0155 * *$ \\
\hline HHLOBST & 6024 & 5012 & 6024 & 6153 & 1.145 & 0.2845 n.s. \\
\hline HHSIZE & 8 & 8.2 & 9 & 8.9 & 1.112 & 0.2916 n.s. \\
\hline HHDEP & 1.3 & 1.47 & 1.3 & 1.58 & 0.006 & 0.9374 n.s. \\
\hline
\end{tabular}

Notes: Significance for p-values: $*<.10 * *<.05 * * *<.01 ;$ n.s. $=$ not significant.

"Non-Deforesters" cleared secondary successional plots previously used in swiddens; "Deforesters" cleared primary forest for swiddens.

Description of variables: HHPLANT = total area (square meters) of crops planted by a household; HHCASH = area (square meters) of land cultivated by a household in cash crops (rice, beans, maize); HHSUBS = area (square meters) of land cultivated by a household in subsistence crops (manioc, bananas/plantains); HHLOBST = estimated income (Honduran Lempiras) to household from males' lobster work during 1991-92; HHSIZE $=$ number of persons in household; HHDEP $=$ household dependency ratio (number of dependants ages 0-14 and 65+ divided by number of workers of ages 15-64). Data above are for the set of households which planted crops and/or had lobster income in 1991 and $1992(n=46)$

\section{Effect of Lobster Income in Deforesting Households}

In Table 4, there is not a significant difference in lobster income between nondeforesting and deforesting households. We still want to know whether lobster income has an effect on forest use. Since households that clear new fields from primary forest have the greatest impact on local forest, it is useful to look more closely at the deforesting households. For the households that choose to clear primary forest, does lobster income 
interact with planting patterns to affect agricultural deforestation? To test the relationships between deforestation, planting patterns, and lobster income, I employ a multiple regression model for households that clear primary forest $(n=19)$. The dependent variable to be explained is the area of land cleared from primary forest (HHDEF). Independent variables are the area devoted to cash crops (HHCASH), the area devoted to subsistence crops (HHSUBS), and lobster wage income (HHLOBST). Hypotheses to test are the following:

(1) Cash crop area per household should be positively associated with deforestation since rice is the largest contributor to primary forest clearing (see Table 2).

(2) Subsistence crop area per household should not be associated with primary forest clearing since the majority of subsistence crops are planted in secondary successional plots (see Table 2).

(3) Lobster income per household should be negatively associated with area of primary forest cleared. If cash crops are the major contributor to primary forest clearing, and if lobster income substitutes for cash crop income, then more lobster income should mean less cash cropping and less primary forest clearing.

\begin{tabular}{|c|c|c|c|c|}
\hline \multicolumn{2}{|c|}{ Dependent variable is: } & \multicolumn{3}{|c|}{ HHDEF } \\
\hline & Coefficient & s.e. of Coeff & t-ratio & p-value \\
\hline Constant & 1259.69 & 991.3 & 1.27 & 0.2232 \\
\hline \multicolumn{5}{|l|}{ Variable } \\
\hline HHCASH & 0.955059 & 0.184 & 5.19 & $0.0001 * * *$ \\
\hline HHSUBS & 0.268474 & 0.08821 & 3.04 & $0.0082 * * *$ \\
\hline HHLOBST & -0.179984 & 0.09772 & -1.84 & $0.0854 *$ \\
\hline
\end{tabular}

Notes: Significance for p-values: $*<.10 * *<.05 * * *<.01$; n.s.=not significant.

Description of variables: HHDEF = area (square meters) deforested, i.e., cleared from primary forest by a household for swidden agriculture; HHCASH = area (square meters) of land cultivated by a household in cash crops (rice, beans, maize); HHSUBS $=$ area (square meters) of land cultivated by a household in subsistence crops (manioc, bananas/plantains); HHLOBST = estimated income (Honduran Lempiras) to household from males' lobster work during 1991-92. Data above are for the set of households which planted crops and/or had lobster income in 1991 and $1992(n=46)$.

The overall results of the regression model are highly predictive (R-squared 70.5\%, Rsquared adjusted $64.6 \%$, F-ratio=12) (Table 5). The results of the regression model for particular dependent variables are as follows:

(1) As hypothesized, cash crop area (HHCASH) positively and significantly predicts area of primary forest cleared (beta coefficient rounded $0.955, \mathrm{p}<.01$ ).

(2) In contrast to the hypothesized relationship, subsistence crop area (HHSUBS) positively and significantly predicts area of primary forest cleared (beta coefficient rounded $0.268, \mathrm{p}<.01$ ). Thus, for deforesting households, subsistence cropping also contributes to cutting of primary forest for agriculture. 
(3) As hypothesized, lobster income (HHLOBST) significantly predicts a decline in primary forest clearing; the sign is negative (beta coefficient rounded -0.180). The probability value of statistical significance is moderate, but still significant $(\mathrm{p}<.10)$.

From the model above, it is apparent that monetary income from lobster work relieves some of the agricultural pressure on primary forest. What explains the pattern of declining cash cropping with increasing income? There are two possibilities. First, time budgets may conflict: as Miskito males spend more time diving, they have less time to clear land and plant cash crops. This explanation, however, is not persuasive because Miskito men in Belen spend only about 28 percent of their time away at sea (Dodds 1994: 195), and this is evenly distributed across the year, not during any particular phase of the agricultural calendar. A second and more likely possibility has to do with the value of cash: given the purchase society orientation of the Miskito (M.Helms 1969,1971), it is more likely that cash from wage labor nullifies the time and effort necessary for cash crops. Wage labor provides sufficient income for households to purchase commercial goods and foodstuffs.

The regression model also tells us more about the "value" of the forest, economically and ecologically. Following the regression model in Table 5, it is possible to estimate the monetary equivalent of forest loss as it is elastic to the amount of lobster income acquired by deforesting households. In economic terms, one hectare of primary forest is "saved" by an income in the local economy of L.55,556 or US $\$ 10,288 .^{5}$ This monetary figure can be converted to lobsters. Since lobster divers are paid L.10/pound of lobster tail, 1 ha of primary forest is "saved" by the harvesting of 5,556 pounds, or 2,520 kg (about two and a half metric tons) of lobster tails. Even though lobster work is displacing local ecological pressure into offshore lobster harvesting, it is less apparent that such displacements are economically or ecologically sustainable over the long term.

\section{Conclusion}

In indigenous subsistence economies, the presence of the market may cause specialization in local food production, thus shifting traditional social arrangements and resource use (C.Behrens 1992); or, market demand may promote over-exploitation of traditional subsistence foods for sale where prices bring a high monetary return to labor (B.Nietschmann 1972, 1973, 1974). R.Godoy et al. (1995) have shown that various degrees of monetary income differentially impact nontimber forest resources for sale by indigenous people. Only recently have anthropological and economic studies attempted to address links between monetary income, subsistence agriculture, and resultant local-level indigenous deforestation (E.Bedoya 1995; C.Behrens et al. 1994; R.Godoy et al. 1997;

5. The multiple regression model describes the relationship between income and primary forest clearing as follows. A one unit increase (in Lempiras) of lobster income (HHLOBST) decreases primary forest clearing (HHDEF) by $0.17998 \mathrm{~m}^{2}$. Thus, 1000 Lempiras income reduces primary forest clearing by approximately $180 \mathrm{~m}^{2}$. To solve for the number of Lempiras which would reduce primary forest cleared by 1 ha, thus giving Lempiras per hectare, we would calculate L. $1,000 \times 10,000 \mathrm{~m}^{2} / 180 \mathrm{~m}^{2}=\mathrm{L}$. 55,556. Since in 1992, US $\$ 1.00=$ L. 5.40, one hectare is "saved" by an income of L.55,556 / L.5.40 / $\$$ US $1.00=\$ 10,288$. Since we know the pay rate for lobster (L.10/lb) we can also calculate that one hectare is "saved" by income generated from L. 55,556 per ha / L. 10 per pound $=5,556$ pounds (rounded). Since $1 \mathrm{~kg}$ is equivalent to 2.2046 pounds, then 1 ha is "saved" by $5,556 \mathrm{lbs} / 2.2046 \mathrm{lbs} / \mathrm{kg}=2,520 \mathrm{~kg}$ of lobster. 
D.Hammond et al. 1995; C.Simmons 1997). Ironically, for the coastal Miskito of Honduras, wage labor conserves rain forest through displacement of agricultural deforestation pressure into wages earned at the expense of Caribbean lobster populations. This finding is in contrast to Nietschmann's (1973) study of the coastal Miskito of Nicaragua, in which increased commoditization of sea turtles threatened local ecological and social welfare. The difference between the two cases may be attributed to the nature of the resource exploited: the sea turtle was a traditional subsistence food in Nicaragua, embedded in important social relations of exchange (e.g., a turtleman should share meat with his mother-in-law); thus as this resource became more commoditized, sale of turtle meat strained traditional patterns of interhousehold exchange and nutritional intake. By contrast, in the case of the Honduran Miskito, lobsters are an offshore resource rarely used as a subsistence food; the effect of lobster work on traditional social relations and subsistence has been through wage labor that provides cash and the ability to buy commercial foodstuffs.

The present study finds variegated ecological and social impacts in the case of Miskito lobster work (see Table 6) as elucidated by a political ecological point of view (Figure 8). Increased linkage to the international export economy appears to reduce human pressure on the local environment; as Miskito males earn more wages in the lobster industry, households clear less primary forest for swidden agriculture, thus producing a local environmental benefit. Also, if lobsters are to be harvested by the fisheries industry, diving may be a more environmentally friendly harvest technology than trapping. Traps catch lobsters of many sizes and many species other than lobster, and lost traps may remain on the sea bottom for years catching and killing for naught. Another effect of cash income for the Miskito of Belen may be an increase in deforestation outside of the Reserve, since, when cash is abundant, the Miskito buy cash crops of the ladino farmers living just outside of the Reserve. From the social point of view, lobster work creates both positive and negative effects for the well-being of the Miskito. Although cash income from lobster work is very profitable and highly desired by the Miskito, lobster work also exposes males to significant risk of injury and death.

\section{Table 6. Costs and Benefits: Ecological and Social Impacts of Miskito Lobster Work \\ COSTS \\ BENEFITS}

ECOLOGICAL

Depletion of Caribbean lobster populations

Increase in primary forest loss outside of Reserve as divers buy cash crops from ladino farmers

SOCIAL

Injury and deaths of divers

Social dislocation

(increase in alcohol and

and other drug consumption)

\author{
Size-specific lobster harvesting \\ (in contrast to lobster cage boats) \\ Reduction of primary forest \\ loss to local swidden \\ agriculture within Reserve
}

Monetary income for desired goods and services (food, clothes, housing, medicine, schooling, church funds) 


\section{Political Ecology of Miskito Lobster Work}

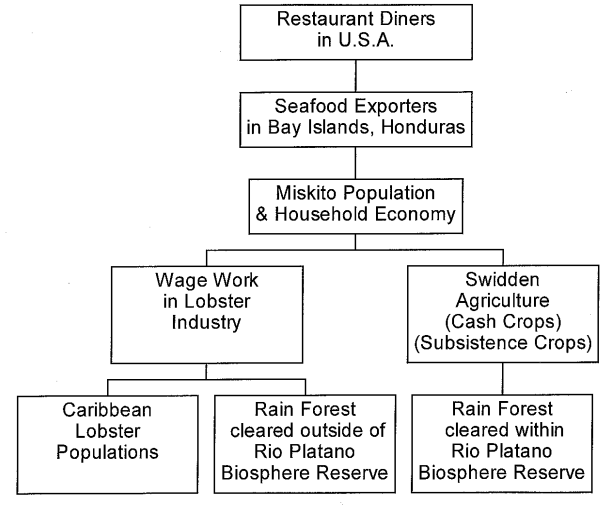

Figure 8. Political ecology of Miskito lobster work.

From the present study, it would be wrong to conclude that the lobster trade should be banned, or that the cash economy should be more intensively promoted to "save" the local rain forest. Ban of the lobster trade has been proposed by some activists as a way to better working conditions (Economist 1997; D.Jukofksy 1994). However, the Miskito do not want to lose their jobs in order to save their human rights. What Miskito lobster divers need is better working conditions, regulations, and training. These needs have only recently begun to be addressed by the Moravian Church, nongovernmental organizations such as Mosquitia Pawisa (MOPAWI), and the Honduran government. Some development workers and foresters have also proposed that the cash economy should be more intensively promoted in order to keep people away from subsistence work in the forest, and that monetary income will thus "save" forest. Though the Miskito do impact their local environment, in particular by clearing forest for fields, it is important to note that the Miskito are long term inhabitants of the region and that their traditional subsistence activities have provided for them sustainably for centuries. Indeed, most of the remaining areas of forest in Central America are in isolated regions long occupied by indigenous peoples (M.Chapin 1992).

Recent conservation strategies such as biosphere reserves attempt to allow for both conservation of natural resources and the need of human inhabitants to maintain their traditional livelihoods (J.Clad 1984, H.Eilers 1985, W.Gregg 1991; B.Houseal et al. 1985). Many difficult problems remain to be solved; the socioecological dimensions of conservation in environmentally threatened areas are often more complex than initial conservation efforts envision (J.Clay 1985, 1992; P.West and S.Brechin 1991; D.Glick and M.Wright 1992; S.Stevens 1997). In the present case, it must be understood that indigenous peoples such as the Miskito need monetary income, yet they must be able to acquire this in a socially and environmentally advantageous manner. Self-determination by indigenous peoples will include choices about participation in both micro- and macrolevel economies that include many difficult social and ecological trade-offs. 


\section{References Cited}

Alvard, Michael

1993 Testing the "Ecologically Noble Savage" Hypothesis: Interspecific Prey Choice by Piro Hunters of Amazonian Peru. Human Ecology 21(4):355-387.

Beckerman, S.

1987 Swidden in Amazonia and the Amazon Rim. In Comparative Farming Systems.

B.L. Turner II and Stephen B. Brush, eds. Pp. 55-94. New York: The Guilford Press.

Bedoya Garland, Eduardo

1995 The Social and Economic Causes of Deforestation in the Peruvian Amazon Basin: Natives and Colonists. In The Social Causes of Environmental Destruction in Latin America. Michael Painter and William H. Durham, eds. Pp. 217-246. Ann Arbor: University of Michigan Press.

Behrens, Clifford

1992 Labor Specialization and the Formation of Markets for Food in a Shipibo Subsistence Economy. Human Ecology 20:435-462.

Behrens, Clifford A., Michael G. Baksh, and Michel Mothes

1994 A Regional Analysis of Barí Land Use Intensification and its Impact on Landscape Heterogeneity. Human Ecology 22(3):279-316.

Boserup, Ester

1981 Population and Technological Change: A Study of Long-Term Trends. Chicago: Chicago University Press.

Brunt, M.A.

1981 La Mosquitia, Honduras: Resources and Development Potential, vol. 1. The Environment. Project Report 110. Surrey: Land Resources Development Center.

Chapin, Mac

1992 Disappearing forests; disappearing peoples. Cultural Survival Quarterly 16(3):63-66.

Clad, James

1984 Conservation and Indigenous Peoples: A Study of Convergent Interests. Cultural Survival Quarterly 8(4):68-73.

Clay, Jason

1985 Parks and People. Cultural Survival Quarterly 9(1):2-5.

1988 Indigenous Peoples and Tropical Forests: Models of Land Use and Management from Latin America. Cambridge: Cultural Survival.

1992 Buying in the Forests: A New Program to Market Sustainably Collected Tropical Forest Products Protects Forests and Forest Residents. In Conservation of Neotropical Forests: Working from Traditional Resource Use. Kent H. Redford and Christine Padoch, eds. Pp. 400-415. New York: Columbia University Press.

Colchester, Marcus

1981 Ecological Modelling and Indigenous Systems of Resource Use: Some Examples from the Amazon of South Venezuela. Antropologica 55:51-72.

Conzemius, Eduard

1932 Ethnographical Survey of the Miskito and Sumu Indians of Honduras and Nicaragua. Smithsonian Institution, Bureau of American Ethnology, Bulletin No. 106. Washington, DC: United States Government Printing Office.

Deere, Carmen Diana, and Alain de Janvry 
1979 A conceptual framework for the empirical analysis of peasants. American Journal of Agricultural Economics, 61 (4):601-611.

Denevan, William M.

1984 Ecological heterogeneity and horizontal zonation of agriculture in the Amazon floodplain. In Frontier Expansion in Amazonia. Marianne Schmink and Charles H. Wood, eds. Pp. 311-336. Gainesville: University of Florida Press.

Dewalt, Billie R. and Pertti J. Pelto, eds.

1985 Micro and Macro Levels of Analysis in Anthropology: Issues in Theory and Research. Boulder: Westview Press.

DIGEPESCA (Dirección General de Pesca y Acuicultura)

1992 Estadísticas del Sector Pesquero, 1990-1991. Boletín No. 10. Tegucigalpa: Secretaría de Recursos Naturales.

1994a Situación Actual de la Pesca y la Acuicultura en Honduras. Tegucigalpa: Secretaría de Recursos Naturales. Septiembre, 1994. Mimeo.

1994b Producción Pesquera Nacional (Reportada) 1994. Tegucigalpa: Secretaría de Recursos Naturales. Mimeo.

Dodds, David J.

1994 The Ecological and Social Sustainability of Miskito Subsistence in the Río Plátano Biosphere Reserve, Honduras: the Cultural Ecology of Swidden Horticulturalists in a Protected Area. Ph.D. dissertation, University of California, Los Angeles. Ann Arbor: University Microfilms International.

1998 Assessing Indigenous Deforestation in Eastern Honduras. Paper presented at the Annual Meetings of the Latin American Studies Association, Chicago, Illinois, September 24.

Dufour, Darna L.

1990 Use of Tropical Rainforest by Native Amazonians. Bioscience 40(9):652-659.

Durham, William H.

1995 Political Ecology and Environmental Destruction in Latin America. In The Social Causes of Environmental Destruction in Latin America. Michael Painter and William H. Durham, eds. Pp. 249-264. Ann Arbor: University of Michigan Press.

The Economist

1997 The Price of Lobster Thermidor. The Economist. August 23:27.

Edelman, Marc

1995 Rethinking the Hamburger Thesis: Deforestation and the Crisis of Central America's Beef Exports. In The Social Causes of Environmental Destruction in Latin America. Michael Painter and William H. Durham, eds. Pp. 25-62. Ann Arbor: University of Michigan Press.

Eilers, Horst

1985 Protected Areas and Indigenous Peoples. Cultural Survival Quarterly 9(1):6-9.

Ethnic Newswatch

1994 America's Taste for Lobster Takes Big Toll. The Ethnic Newswatch/Oakland Post 30(89):1.

FAO (Food and Agriculture Organization)

1997 Fishstat-PC. Release 5095/97 for Computerized Database of Yearbook of Fishery Statistics of Catches and Landings. FAO: Rome. http://www.fao.org.

Glick, Dennis and Michael Wright

1992 The Wildlands and Human Needs Program: Putting Rural Development to Work for Conservation. In Conservation of Neotropical Forests: Working from Traditional 
Resource Use. Kent H. Redford and Christine Padoch, eds. Pp. 259-275. New York: Columbia University Press.

Godoy R., N. Brokaw and D. Wilkie

1995 The Effect of Income on the Extraction of Non-Timber Tropical Forest Products

- Model, Hypotheses, and Preliminary Findings from the Sumu Indians of Nicaragua. Human Ecology 23(1): 29-52.

Godoy, R., K. O’Neill, S. Groff, P. Kostishack, A. Cubas, J. Demmer, K. Mcsweeney, D.

Wilkie, N. Brokaw, and M. Martinez

1997 Household Determinants of Deforestation by Amerindians in Honduras. World Development 25(6): 977-987.

Gradwohl, Judith and Russell Greenberg 1988 Saving the Tropical Forests. Washington, DC: Island Press.

Greenberg, J.B., and T.K. Park 1994 Political Ecology. Journal of Political Ecology 1:1-12.

Gregg, William P., Jr.

1991 MAB Biosphere Reserves and Conservation of Traditional Land Use Systems. In Biodiversity: Culture, Conservation, and Ecodevelopment. Margery L. Oldfield and Janis B. Alcorn, eds. Pp. 274-294. Boulder: Westview Press.

Hames, Raymond

1987 Game Conservation or Efficient Hunting? In the Question of the Commons: the Culture and Ecology of Communal Resources. B. McCay and J. Acheson, eds. Pp. 92-107. Tucson: University of Arizona Press.

1991 Wildlife Conservation in Tribal Societies. In Biodiversity: Culture, Conservation, and Ecodevelopment. Margery L. Oldfield and Janis B. Alcorn, eds. Pp. 172-199. Boulder: Westview Press.

Hammond, D.S., P.M. Dolman, and A.R. Watkins

1995 Modern Ticuna Swidden-Fallow Management in the Colombian Amazon: Ecologically Integrating Market Strategies and Subsistence-Driven Economies? Human Ecology 23(3): 335-356.

Hecht, Susanna B.

1992 Logics of Livestock and Deforestation. In Development or Destruction?: The Conversion of Tropical Forest to Pasture in Latin America. Downing, Theodore E., Susanna B. Hecht, Henry A. Pearson, and Carmen Garcia-Downing, eds. Pp. 7-25. Boulder: Westview Press.

Hecht, S.B. and A. Cockburn 1989 Fate of the Forest. London: Verso.

Helms, Mary W.

1969 The Purchase Society: Adaptation to Economic Frontiers. Anthropological Quarterly 42(4):325-342.

1971 Asang: Adaptations to Culture Contact in a Miskito Community. Gainesville: University of Florida Press.

Henley, Paul

1982 The Panare: Tradition and Change on the Amazon Frontier. New Haven: Yale University Press.

Herlihy, Peter H.

1990 "Wildlands" Conservation in Central America During the 1980s: A Geographical Perspective. Conference of Latin Americanist Geographers 17/18:3143. 
1997 Indigenous Peoples and Biosphere Reserve Conservation in the Mosquitia Rain Forest Corridor, Honduras. In Conservation Through Cultural Survival: Indigenous Peoples and Protected Areas. Stan Stevens, ed.. Pp. 99-133. Washington, DC: Island Press.

Herlihy, Peter H. and Laura Hobson Herlihy

1992 La Herencia Cultural de la Reserva de la Biósfera del Río Plátano: Un Area De Confluencias Étnicas En La Mosquitia. In La Reserva de la Biósfera del Río Plátano: Herencia de Nuestro Pasado. Vicente Murphy, ed. Pp. 9-13. Tegucigalpa: Paseo Pantera.

Herlihy, Peter H. and Andrew P. Leake

1993 Tierras Indígenas de La Mosquitia-1992: Zonas de Subsistencia. Tegucigalpa: Instituto Geográfico Nacional. Map.

Houseal, B., C. MacFarland, G. Archibold, and A. Chiari

1985 Indigenous Cultures and Protected Areas in Central America. Cultural Survival Quarterly 9(1):10-20.

ITA (International Trade Administration) 1993 Honduras-Shrimp and Fish Industry-Industry Analysis-ISA890. Item ID: IT MARKET 111110812, May 25, 1993. National Trade Data Bank-The Export Connection.

Johnson, Allen W.

1975 Time allocation in a Machiguenga community. Ethnology 14:301-310.

1989 How the Machiguenga Manage Resources: Conservation or Exploitation of Nature? In Resource Management in Amazonia: Indigenous and Folk Strategies. W. Balée and D. Posey, eds. Pp. 213-222. New York: New York Botanical Gardens.

Johnson, Tim

1993 Indians Risk Death Diving for Lobsters. Miami Herald, December 20: A1.

Jukofsky, Diane.

1994 Lobster Tales. E Magazine 5(3):21ff.

La Prensa

1997 Un Millar de Indígenas Misquito Postrados por Bucear. Tegucigalpa, La Prensa Newspaper, June 9.

Lathrap, D.W.

1977 Our father the cayman, our mother the gourd: Spinden revisited, or a unitary model for the emergence of agriculture in the New World. In C.A. Reed, ed. Origins of Agriculture. Pp. 713-751. The Hague: Mouton.

Loker, William

1995 Surviving on Chaos: Land-Use Strategies in the Peruvian Amazon, 1987-92. Culture and Agriculture 51/52:7-12.

Miller, Walstead and Miriam King Dagen

1990 Encuesta: Buzos Afectados por la "Enfermedad Del Buzo." Tegucigalpa: PROMEBUZ/MOPAWI. Mimeo.

Moran, Emilio, ed. 1983 The Dilemma of Amazonian Development. Boulder: Westview Press.

Moran, Emilio

1990 Levels of Analysis and Analytical Level Shifting: Examples from Amazonian Ecosystem Research. In The Ecosystem Approach in Anthropology: From Concept to Practice. Emilio Moran, ed. Pp. 279-319. Ann Arbor: University of Michigan Press. 
Nash, June

1994 Global Integration and Subsistence Insecurity. American Anthropologist 96(1): 7-30.

Nations, James D.

1992 Terrestrial Impacts in Mexico and Central America. In Development or Destruction?: The Conversion of Tropical Forest to Pasture in Latin America. Downing, Theodore E., Susanna B. Hecht, Henry A. Pearson, and Carmen GarciaDowning, eds. Pp. 191-203. Boulder: Westview Press.

Nietschmann, Bernard

1972 Hunting and Fishing Focus among the Miskito Indians, Eastern Nicaragua. Human Ecology 1(1):41-67.

1973 Between Land and Water: The Subsistence Ecology of the Miskito Indians, Eastern Nicaragua. New York: Seminar Press.

1974 When the Turtle Collapses, the World Ends. Natural History 83(6):34-43.

1995 Conservación, Autodeterminación y el Area Protegida Costa Miskita, Nicaragua. Mesoamerica 29:1-55.

1997 Protecting Indigenous Coral Reefs and Sea Territories, Miskito Coast, Raan, Nicaragua. In Conservation Through Cultural Survival: Indigenous Peoples and Protected Areas. Stan Stevens, ed.. Pp. 193-224. Washington, DC: Island Press.

Oldfield, Margery L., and Janis B. Alcorn, eds.

1991 Biodiversity: Culture, Conservation, and Ecodevelopment. Boulder: Westview Press.

Painter, Michael

1995 Introduction: Anthropological Perspectives on Environmental Destruction. In The Social Causes of Environmental Destruction in Latin America. Michael Painter and William H. Durham, eds. Pp. 1-20. Ann Arbor: University of Michigan Press.

Proyecto Nautilo

1993 Proyecto Nautilo Para el Buceo Seguro y Desarrollo de la Moskitia: Estudio Socioeconómico, Laboral y de Salud de los Buzos: Informe de Primeros Resultados con Conclusiones y Recomendaciones. Tegucigalpa: Ministerio de Salud Pública, Programa de Salud de los Trabajadores, Fuerza Naval (Escuela de Buceo), IHRM, PROMEBUZ.

Redford, Kent H. and Christine Padoch, eds.

1992 Conservation of Neotropical Forests: Working from Traditional Resource Use. New York: Columbia University Press.

Ring, Wilson

1992 Lobster Dives Bring Profits and Death: Few Safety Measures in Honduras.

Chicago Tribune, April 26: C23.

Schmink, Marianne and Charles Wood

1987 The "Political Ecology" of Amazonia. In Lands at Risk in the Third World:

Local Level Perspectives. Peter D. Little, Michael M. Horowitz, and A. Endre Nyerges, eds. Pp. 38-57. Boulder: Westview Press.

Schwarz, Norman B.

1995 Colonization, Development, and Deforestation in Petén, Northern Guatemala. In The Social Causes of Environmental Destruction in Latin America. Michael Painter and William H. Durham, eds. Pp. 101-130. Ann Arbor: University of Michigan Press.

Simmons, C.L. 
1997 Forest Management Practices in the Bayano Region of Panama: Cultural Variations. World Development 25(6): 989-1000.

Stassel, Stephanie

1992 Profile: Tom Millington, Dr. Deep; A family practitioner travels to Honduras to care for lobster divers with "the bends." Los Angeles Times, October 8: J12.

Stevens, Stan

1997 Introduction. In Conservation Through Cultural Survival: Indigenous Peoples and Protected Areas. Stan Stevens, ed. Pp. 1-7. Washington, DC: Island Press.

Stocks, Anthony

1987 Tropical Forest Development in Peru. Development Anthropology Network/

Bulletin of the Institute for Development Anthropology 5(2): 1-8.

Stonich, Susan C.

1993 "I am Destroying the Land!" The Political Ecology of Poverty and Environmental Destruction in Honduras. Boulder: Westview Press.

Uhl, Cristopher, and Carl F. Jordan

1984 Succession and nutrient dynamics following forest cutting and burning in Amazonia. Ecology 65(5):1476-1490.

USDOC (United States Department of Commerce)

1989-1992 U.S. Imports for Consumption: Harmonized TSUSA, Commodity by Country of Origin. Document FT247. U.S. Department of Commerce, Bureau of Census.

1996 Stat-USA. National Trade Data Bank and Economic Bulletin Board. U.S. Department of Commerce. http://www.stat-usa.gov.

West, Patrick C. and Steven R. Brechin

1991 Resident Peoples and National Parks: Social Dilemmas and Strategies in International Conservation. Tucson: University of Arizona Press.

\section{Abstract}

A political ecological research orientation elucidates the effects of Miskito wage work in the Honduran lobster export industry. Miskito wage labor conserves local rain forest by displacing agricultural deforestation pressure into wages. These wages, however, are earned in an industry that depletes Caribbean lobster populations and which increases risk of injury and death to divers.

Key words: political ecology; deforestation; swidden agriculture; fisheries; conservation

\section{Resumé}

Une approche théorique basée sur une orientation de recherche politico-écologique clarifie les effets du travail salarié des Miskito dans l'industrie d'exportation du homard au Honduras. Du fait que les salaires diminuent le besoin d'argent, le travail salarié diminue le déboisement aux buts agricoles et préserve la forêt vierge. Cependant les salaires générés par cette industrie contribuent de façon significative à diminuer la population de homards dans les Caraïbes et augment la risque d'accidents et de dangers de mort parmi les plongeurs.

Mots clefs: politico-écologique, déboisement, agriculture sur-bruli, pêche industrielle, conservation. 


\section{Resumen}

Una investigación desde la perspectiva de la ecología política es ulitizada para explicar los efectos de trabajos jornales en la industria pesquera de exportación de langostas en Honduras. Entre los Miskito el dinero que viene de trabajos jornales ayuda a reducir las presiones de desforestación agrícola y a a conservar los bosques tropicales locales. De cualquier modo, estos sueldos se ganan en una industria que disminuye las poblaciones de langostas del caribe y que aumentan los riesgos a los buzos de graves lesiones or muerte.

Palabras claves: ecología política, desforestación, tumba y roza, pesca, conservación. 